
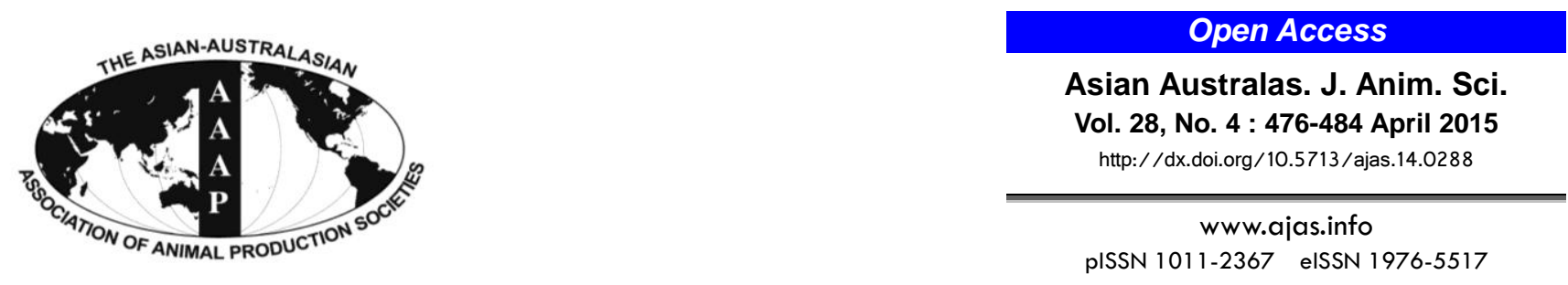

\title{
Genetic Parameters for Linear Type Traits and Milk, Fat, and Protein Production in Holstein Cows in Brazil
}

\author{
Rafael Viegas Campos ${ }^{1,2}$, Jaime Araujo Cobuci ${ }^{1}$, Elisandra Lurdes Kern ${ }^{1, *}$, \\ Cláudio Napolis Costa ${ }^{3}$, and Concepta Margaret McManus ${ }^{4}$ \\ ${ }^{1}$ Animal Science Department, Federal University of Rio Grande do Sul, Porto Alegre, RS 91540-000, Brazil
}

\begin{abstract}
The objective of this study was to estimate genetic and phenotypic parameters for linear type traits, as well as milk yield (MY), fat yield (FY) and protein yield (PY) in 18,831 Holstein cows reared in 495 herds in Brazil. Restricted maximum likelihood with a bivariate model was used for estimation genetic parameters, including fixed effects of herd-year of classification, period of classification, classifier and stage of lactation for linear type traits and herd-year of calving, season of calving and lactation order effects for production traits. The age of cow at calving was fitted as a covariate (with linear and quadratic terms), common to both models. Heritability estimates varied from 0.09 to 0.38 for linear type traits and from 0.17 to 0.24 for production traits, indicating sufficient genetic variability to achieve genetic gain through selection. In general, estimates of genetic correlations between type and production traits were low, except for udder texture and angularity that showed positive genetic correlations $(>0.29)$ with MY, FY, and PY. Udder depth had the highest negative genetic correlation $(-0.30)$ with production traits. Selection for final score, commonly used by farmers as a practical selection tool to improve type traits, does not lead to significant improvements in production traits, thus the use of selection indices that consider both sets of traits (production and type) seems to be the most adequate to carry out genetic selection of animals in the Brazilian herd. (Key Words: Dairy Cattle, Functional Trait, Genetic Correlation, Heritability, Selection)
\end{abstract}

\section{INTRODUCTION}

Selection in commercial herds of dairy cattle in Brazil is based almost exclusively on production traits, especially those directly related to the increase in income from dairy farming (volume, fat and protein of milk), while improved milk composition may receive higher premiums depending on the region (Cardoso et al., 2004; Boligon et al., 2005).

Some studies (Degroot et al., 2002; Perez-Cabal et al., 2006; Lagrotta et al., 2010) have shown that production traits are negatively associated with many type traits. Once adequate selection is carried out, these can effectively

\footnotetext{
* Corresponding Author: Elisandra Lurdes Kern. Tel: +55-5133087421, E-mail: elikern@ hotmail.com

${ }^{2}$ Department of Animal Science, Federal Institute Catarinense, Santa Rosa do Sul, SC 88965-000, Brazil.

${ }^{3}$ Embrapa Dairy Cattle, Juiz de Fora, MG 36038-330, Brazil.

${ }^{4}$ Department of Animal Science, University of Brasília, Campus Darcy Ribeiro, Brasília, DF 70910-900, Brazil.

Submitted Apr. 18, 2014; Revised Jul. 14, 2014; Accepted Aug. 21, 2014
}

contribute to the improvement of milk quality by reducing the incidence of problems related with udder health at calving, as well as the locomotor system, among others, in addition to providing comfort for the cow due to lower production stress, ensuring that animals in the herd become increasingly healthier (Simianer et al., 1991).

According to Darili et al. (2008), when selection for linear type traits is associated with production traits, greater economic efficiency can be expected. This occurs mainly through the reduction of production costs; for example, those related with veterinary care and medications as well as increasing the productive life of cows in the herd.

Another important point is the growing demand for good management practices and their influence on productivity and welfare of cows managed in production systems in Brazil (Costa et al., 2013) to meet increasing domestic and external demands as established by Normative Instruction 62 (Brazil, 2011).

Many of the type and production traits are inherited independently and, therefore, selection should be practiced

Copyright $@ 2015$ by Asian-Australasian Journal of Animal Sciences This is an open-access article distributed under the terms of the Creative Commons Attribution Non-Commercial License (http://creativecommons.org/licenses/by-nc/3.0/), which permits unrestricted non-commercial use, distribution, and reproduction in any medium, provided the original work is properly cited. 
on both (Wenceslau et al., 2000). However, the mean to low heritabilities hinder direct selection for linear type traits (Short and Lawlor, 1992). A selection index that weights linear type and production traits according to their economic importance is being used as an alternative in many countries (Vanraden et al., 2004).

Few studies have been carried out aimed at simultaneous estimation of genetic parameters among linear type and production traits in dairy cattle in Brazil. These include McManus and Saueressig (1998), Freitas et al. (2002) and Esteves et al. (2004) with Holstein as well as Rennó et al. (2003) and Lagrotta et al. (2010) with Brown Swiss and Dairy Gyr, respectively. Considering the importance of linear type and production traits for dairy production, the aim of this study was estimate (co) variances, heritabilities and correlations between linear type traits with milk yield (MY), fat yield (FY), and protein yield (PY) in Holstein cows reared in Brazil, to support future implementation of selection/genetic evaluation through selection indices.

\section{MATERIAL AND METHODS}

The data set was provided by the Brazilian Association of Holstein Breeders (ABCBRH), and included recording of MY, FY, and PY and type traits resulting in 71.282 records. The classifications of cows were realized by technicians of ABCBRH between 1994 and 2004 through direct or visual measurements of the morphology of animals expressed as a score on a scale which ranged from one (1) to nine (9), according to the Canadian classification system. More details can be obtained in Campos (2012).

The Brazilian system of linear type traits classification contemplated 21 traits divided in sections: conformation, rump, legs and feet, front udder, rear udder, mammary system and dairy form. The linear classification records were first edited in SAS - Statistical Analysis System, version 9.2 (SAS Institute Inc., Cary, NC, USA) to include lactation order (1 to 5), year of classification, year of calving (1994 through 2004) and final score (57 to 90 points) with a single classification per cow. Subsequently, the number of classifications per classifier and size of contemporary group of animals (herd-year classification) was edited, eliminating those groups that did not contain at least two observations and two progenies per bull in at least two herds.

The classification of each cow was used if held between the first and tenth month of lactation. Ten monthly classes were formed related to stage of lactation of cows at the time of their classification, these being between 5 and 305 days in milk. This led to a file containing 26,558 linear classification records of 21 traits with scores ranging 1 to 9 , as well as the final score, that expresses the balance between all type traits. Finally, the classification and production files of the cows were joined, with animals belonging to contemporary groups that did not contain at least two classification per herd-year for type traits and two calvings per herd-year for the productive traits again and a minimum of two progeny per bull in two herds being eliminated, resulting in a total of 18,831 records of linear classification and of MY, FY and PY in 305 days in milk with cows aged 18 to 112 months, daughters of 768 bulls, measured in 495 herds in the period 1994 through 2004. The months which included the classifications and/or calving were grouped into four seasons (January to March, April to June, July to September and October to December).

The bivariate model was used for estimation of genetic parameters for linear type and production traits included the fixed effects of herd-year classification $(2,485)$, period of classification (4), classifier (13), stage of lactation (10) and age of cow at classification (covariate with linear and quadratic effects) for linear type traits and the fixed effects of herd-year of calving (1,718), season of calving (4), lactation order (5) and age of cow at calving (covariate with effect linear and quadratic), for the MY, FY, and PY. The random effects of animal and residual effects were common to both models and considered the relationship matrix that included 48,833 animals. More details can be obtained in Campos (2012). The statistical effects described above can be represented in matrix form as follows:

$$
\left[\begin{array}{l}
y_{1} \\
y_{2}
\end{array}\right]=\left[\begin{array}{cc}
X_{1} & 0 \\
0 & X_{2}
\end{array}\right] \cdot\left[\begin{array}{l}
\beta_{1} \\
\beta_{2}
\end{array}\right]+\left[\begin{array}{cc}
Z_{1} & 0 \\
0 & Z_{2}
\end{array}\right] \cdot\left[\begin{array}{l}
u_{1} \\
u_{2}
\end{array}\right]+\left[\begin{array}{l}
e_{1} \\
e_{2}
\end{array}\right]
$$

where: $y_{i}$ is the vector of observations to the $\mathrm{i}^{\text {th }}$ linear type trait $(i=1)$ and the MY, FY, and PY in 305 days in milk $(i=2) ; \beta_{i}$ is the vector of fixed effects to the $\mathrm{i}^{\text {th }}$ trait; $u_{i}$ is the vector of random effects of animal to the $\mathrm{i}^{\text {th }}$ trait; $e_{i}$ is the vector of random effects residual to the $\mathrm{i}^{\text {th }}$ trait; $X_{i}$ and $Z_{i}$ are incidence matrices relating the observations of $i^{\text {th }}$ trait to the fixed and random effects of animal, respectively. It is assumed that:

$$
\operatorname{var}\left[\begin{array}{l}
a_{1} \\
a_{2} \\
e_{1} \\
e_{2}
\end{array}\right]=\left[\begin{array}{cccc}
g_{11} A & g_{12} A & 0 & 0 \\
g_{21} A & g_{22} A & 0 & 0 \\
0 & 0 & r_{11} I & r_{12} I \\
0 & 0 & r_{21} I & r_{22} I
\end{array}\right]
$$

where: $g_{i j}$ are the elements of the matrix G, related to the additive genetic (co) variance or effects of animals, with each element defined as: $g_{11}$ is the additive genetic variance for the direct effect of linear trait, $i=1 ; g_{12}=g_{21}$ is the additive genetic covariance between two traits; $g_{22}$ is the additive genetic variance for direct effects of production 
traits, $i=2 ; A$ is the relationship matrix between 48,833 animals. $r_{i j}$ are the elements of the $\mathrm{R}$ matrix, related to the (co) variance of residual effects, with each element defined as: $r_{11}$ is the residual variance for the linear trait, $i=1 ; r_{12}=$ $r_{21}$ is the residual covariance between the two traits; $r_{22}$ is the residual variance for production trait, $i=2, I$ is the identity matrix which assumes independence of errors with the same variance.

Estimates of (co)variance components were obtained by the restricted maximum likelihood (REML) using multiple trait derivative free REML program (Boldman et al., 1995) by bivariate analysis with a convergence criterion less than $10^{-9}$.

Additive genetic (co)variances were used in bivariate analyzes, to obtain the genetic and phenotypic correlations. Genetic variances were obtained using the initial values of the variances from the univariate analyses and after each convergence program was restarted using the values obtained in the previous processing as priors.

The heritability $\left(\hat{h}^{2}\right)$ for type and yield traits were estimated as $\hat{h}^{2}=\frac{\hat{\sigma}_{a}}{\hat{\sigma}_{a}+\hat{\sigma}_{e}}$ where $\hat{\sigma}_{a}$ is the additive genetic variance due to the additive effects of alleles at the loci controlling the quantitative trait; $\hat{\sigma}_{e}$ is the residual variance resulting from the non-additive genetic variances and variances caused by the environment. Genetic correlations $\left(\hat{\mathrm{r}}_{\mathrm{G}(x y)}\right)$ between type traits were calculated as $\hat{\mathbf{r}}_{\mathrm{G}(x y)}=\frac{\operatorname{Cov}_{\mathrm{G}(x y)}}{\sqrt{\hat{\sigma}_{G(x)} \cdot \hat{\sigma}_{G(y)}}}$, where $\operatorname{Cov}_{\mathrm{G}(x y)}$ is the genetic covariance between $\mathrm{x}$ and $\mathrm{y}$ traits; $\hat{\sigma}_{G(x)}$ and $\hat{\sigma}_{G(y)}$ are the additive genetic variances of $\mathrm{x}$ and $\mathrm{y}$ traits, respectively. Phenotypic correlations $\left(\hat{\mathrm{r}}_{\mathrm{P}(x y)}\right)$ were calculated as $\hat{\mathrm{r}}_{\mathrm{P}(x y)}=\frac{\operatorname{Cov}_{\mathrm{P}(x y)}}{\hat{\sigma}_{P(x)} \cdot \hat{\sigma}_{P(y)}}$, where $\operatorname{Cov}_{\mathrm{P}(x y)}$ is the phenotypic covariance between $\mathrm{x}$ and $\mathrm{y}$ traits and $\left(\hat{\sigma}_{P(x)}\right)$ and $\left(\hat{\sigma}_{P(y)}\right)$ are the phenotypic standard deviations of $\mathrm{x}$ and $\mathrm{y}$, respectively.

\section{RESULTS AND DISCUSSION}

The means and standard deviations for MY, FY, and PY in Holstein cows in 305 days in milk were 8,415.22 $1,910.17 \mathrm{~kg}, 276.89 \pm 66.63 \mathrm{~kg}$ and $253.56 \pm 57.21 \mathrm{~kg}$, respectively. The fact that all cows in this study had their productions controlled and were classified linearly for type by Brazilian Association of Holstein Breeders (ABCBRH) technicians characterizes a genetically superior population, presumably on farms with higher technological levels, which explains the lower MY, FY, and PY reported by Costa et al. (2011) in the genetic evaluation of the national breed.

The evolution of Brazilian milk production showed continuous growth over the past few years, accompanied by an increase in the price per liter of milk paid to farmers. However, with this growth, there has been a rise in costs (Martins and Carneiro, 2012), which turn, decrease profitability. One way of maximizing profit is the reduction of costs per cow. For this, a herd requires healthy cows, adapted to the environment with good reproductive capacity, ease of calving, locomotion and appropriate mammary system.

Thus, the linear classification of type traits becomes an important tool in the decision making process in the herds, as it aims to select animals that express phenotypic traits which will give greater productive life in the herd (PérezCabal and Alenda, 2002; Posadas et al., 2008) through their improved productive and reproductive potential. Kern et al. (2014) studied the relationship between linear type traits and longevity of cows through factor analysis and reported that selection based on the final score together with the traits related to mammary system (cows with deep, wide, soft, elastic udder, with strong central ligament, cows with good bone quality) would result in more functional cows and consequently with higher MY and productive life in the herd.

Considering the seven sections related to the type traits and the final score (FS), it is noted that, in general, the cows of this population would be classified as good $(\mathrm{B}+)$, as the average final score was greater than 80 points (Table 1) according to the criteria of ABCBRH (Valotto and Neto, 2010).

Among the 21 type traits, the observed type traits of chest width, fore udder attachment and rear udder width (Table 1) had mean scores well below the recommended ideal score for the breed (Costa et al., 2011). According to Mark and Sullivan (2006), mammary system traits should receive greater selection emphasis when the objective is to improve type, as these are directly related to udder health and consequently to economic impacts in the dairy herd. Lower scores for these last two traits reveal some difficulty of these cows in supporting high MY.

Greater chest width is important for the physiological ability of the cow to maintain good body condition and the balance between the strength and dairy form. It also enables greater food intake. The traits related to stature, udder cleft, rump width and those of the front udder section showed higher genetic variability among the type traits (Table 1). On the other hand, the lowest estimates of genetic variance were observed for the udder texture, foot angle and top line traits which cause lower responses to selection.

The mean estimates of heritability for the 21 linear type traits and final score ranged from low (0.09) for udder texture and foot angle to high (0.38) for teat length, 
Table 1. Average (standard deviation), ideal score, average estimates of variance components for linear type traits obtained through bivariate analysis with milk, fat and protein yields

\begin{tabular}{|c|c|c|c|c|c|c|c|c|c|c|c|}
\hline \multirow{3}{*}{ Type traits } & \multirow{3}{*}{$\begin{array}{c}\text { Average } \\
\text { (standard deviation) }\end{array}$} & \multirow{3}{*}{$\begin{array}{l}\text { Ideal } \\
\text { score }\end{array}$} & \multicolumn{9}{|c|}{ Variance components $^{1}$} \\
\hline & & & \multicolumn{3}{|c|}{ Milk } & \multicolumn{3}{|c|}{ Fat } & \multicolumn{3}{|c|}{ Protein } \\
\hline & & & $\hat{\sigma}_{a}^{2}$ & $\hat{\sigma}_{e}^{2}$ & $\hat{\sigma}_{p}^{2}$ & $\hat{\sigma}_{a}^{2}$ & $\hat{\sigma}_{e}^{2}$ & $\hat{\sigma}_{p}^{2}$ & $\hat{\sigma}_{a}^{2}$ & $\hat{\sigma}_{e}^{2}$ & $\hat{\sigma}_{p}^{2}$ \\
\hline \multicolumn{12}{|l|}{ Conformation/capacity } \\
\hline Stature & $7.229(1.287)$ & 7.0 & 0.50 & 0.84 & 1.34 & 0.51 & 0.84 & 1.34 & 0.50 & 0.84 & 1.34 \\
\hline Top line & $5.340(1.063)$ & 7.0 & 0.13 & 0.63 & 0.76 & 0.13 & 0.63 & 0.76 & 0.13 & 0.63 & 0.76 \\
\hline Weight & $6.882(1.232)$ & 9.0 & 0.27 & 0.77 & 1.04 & 0.27 & 0.77 & 1.04 & 0.27 & 0.77 & 1.04 \\
\hline Chest width & $5.878(1.249)$ & 7.0 & 0.21 & 0.96 & 1.17 & 0.21 & 0.96 & 1.17 & 0.20 & 0.96 & 1.17 \\
\hline Body depth & $6.271(1.025)$ & 7.0 & 0.19 & 0.66 & 0.85 & 0.19 & 0.66 & 0.85 & 0.19 & 0.66 & 0.85 \\
\hline Loin strength & $6.587(1.230)$ & 9.0 & 0.26 & 0.95 & 1.21 & 0.26 & 0.95 & 1.21 & 0.25 & 0.95 & 1.21 \\
\hline \multicolumn{12}{|l|}{ Rump } \\
\hline Rump angle & $5.010(0.929)$ & 5.0 & 0.22 & 0.60 & 0.82 & 0.22 & 0.56 & 0.82 & 0.22 & 0.60 & 0.82 \\
\hline Rump width & $6.620(1.203)$ & 9.0 & 0.35 & 0.72 & 1.07 & 0.35 & 0.72 & 1.07 & 0.35 & 0.72 & 1.07 \\
\hline \multicolumn{12}{|l|}{ Legs and Feet } \\
\hline Foot angle & $5.143(1.250)$ & 7.0 & 0.10 & 1.02 & 1.13 & 0.10 & 1.02 & 1.13 & 0.10 & 1.02 & 1.13 \\
\hline Bone quality & $6.478(1.287)$ & 9.0 & 0.26 & 1.11 & 1.37 & 0.29 & 0.11 & 1.37 & 0.26 & 1.11 & 1.37 \\
\hline Side view rear legs & $5.620(1.101)$ & 5.0 & 0.24 & 0.91 & 1.15 & 0.24 & 0.91 & 1.15 & 0.24 & 0.91 & 1.15 \\
\hline \multicolumn{12}{|l|}{ Front udder } \\
\hline Fore udder attachment & $5.992(1.514)$ & 9.0 & 0.34 & 1.59 & 1.93 & 0.34 & 1.58 & 1.91 & 0.34 & 1.59 & 1.93 \\
\hline Front teat placement & $4.414(1.159)$ & 5.0 & 0.34 & 0.89 & 1.22 & 0.34 & 0.89 & 1.22 & 0.34 & 0.89 & 1.22 \\
\hline Teat length & $5.212(1.030)$ & 5.0 & 0.39 & 0.64 & 1.02 & 0.39 & 0.64 & 1.02 & 0.39 & 0.64 & 1.02 \\
\hline \multicolumn{12}{|l|}{ Rear udder } \\
\hline Rear udder height & $6.483(1.220)$ & 9.0 & 0.28 & 1.01 & 1.29 & 0.28 & 1.01 & 1.29 & 0.28 & 1.01 & 1.29 \\
\hline Rear udder width & $5.890(1.445)$ & 9.0 & 0.25 & 1.20 & 1.45 & 0.25 & 1.20 & 1.45 & 0.25 & 1.20 & 1.45 \\
\hline Rear teat placement & $6.368(1.153)$ & 5.0 & 0.21 & 0.94 & 1.15 & 0.21 & 0.94 & 1.15 & 0.21 & 0.94 & 1.15 \\
\hline \multicolumn{12}{|l|}{ Mammary system } \\
\hline Udder depth & $4.795(1.152)$ & 5.0 & 0.27 & 0.81 & 1.08 & 0.27 & 0.81 & 1.08 & 0.27 & 0.81 & 1.08 \\
\hline Udder texture & $6.691(1.150)$ & 9.0 & 0.09 & 0.89 & 0.98 & 0.08 & 0.89 & 0.98 & 0.09 & 0.89 & 0.98 \\
\hline Udder cleft & $6.398(1.438)$ & 9.0 & 0.37 & 1.37 & 1.74 & 0.37 & 1.37 & 1.74 & 0.37 & 1.37 & 1.74 \\
\hline \multicolumn{12}{|l|}{ Dairy form } \\
\hline Angularity & $6.521(1.138)$ & 9.0 & 0.18 & 0.72 & 0.89 & 0.17 & 0.72 & 0.89 & 0.17 & 0.72 & 0.89 \\
\hline Final score & $81.320(3.338)$ & $>80$ & 1.16 & 4.74 & 5.90 & 1.17 & 4.73 & 5.90 & 1.19 & 4.72 & 5.91 \\
\hline
\end{tabular}

$\hat{\sigma}_{a}^{2}$, genetic variance components; $\hat{\sigma}_{e}^{2}$, residual variance components; $\hat{\sigma}_{p}^{2}$ phenotypic variance components.

respectively (Figure 1). These low heritabilities may suggest lower genetic gains, whereas improvements in environmental factors that affect the animals can lead to greater gains in these phenotypic traits. A more detailed discussion of this topic can be seen in Campos et al. (2012) who studied the same 21 linear type traits and final score. However, a multiple trait model was used to estimate heritability simultaneously.

The magnitude of the estimates of genetic variance and heritability obtained for MY, FY, and PY suggests that genetic gain can be achieved in the population by selection for increased MY and its constituents of FY and PY (Table 2), as heritability of 0.21 obtained for MY, 0.24 for FY and 0.17 for PY infer that a considerable portion of the total variation of these traits is due to the additive effect of genes.

These values confirm those estimated for Holstein herds in Brazil and in other countries such as Iran, Colombia, Norway, United States, Denmark and France where values ranged between 0.13 to 0.44 for MY, 0.22 to 0.42 for $F Y$ and 0.09 to 0.40 for PY (Misztal et al., 1992; Boligon et al., 2005; Darili et al., 2008, Silva et al., 2011).

In general, the genetic, environmental and phenotypic covariances from bivariate analyze between type and production traits showed small differences. The genetic covariance means ranged from negative to positive and were higher among type traits and MY compared to 305 days FY or PY (Table 3).

Inferences on the genetic relationships between these traits can be made based on the variances and covariances of each, indicating that little or no change can be observed in the productivity of cows when selection is practiced aiming at the improvement of type traits, that comprise 


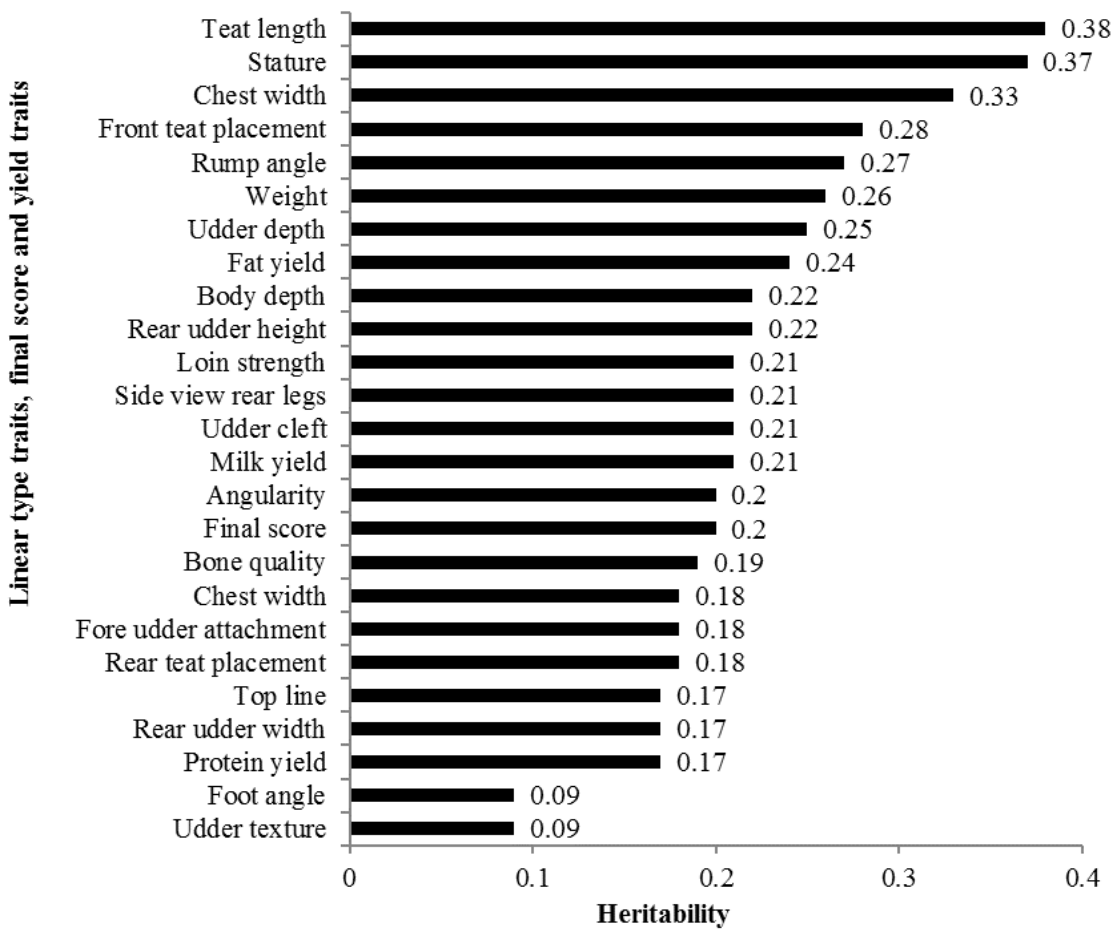

Figure 1. Average estimates of heritability for linear type and production traits in Holstein cows in Brazil.

mainly the rump, feet and legs and front udder sections and, moreover, that the prevalence of the emphasis on selection for increased MY in Brazilian herds can lead to a worsening of some of these traits, due to the direction and magnitude of their genetic correlations (Table 4).

Studies have shown that the direct selection for milk production can increase, in the long term, the deterioration of functional (fertility and longevity) and type traits, increasing the involuntary disposal of cows and significantly decreasing their longevity (Perez Cabal et al., 2006; Lagrotta et al., 2010), which are undesirable traits.

Because of their economic importance, traits related to health, conformation, reproduction and longevity have been included in selection programs in different countries (Miglior et al., 2005). The purpose of the inclusion of some of these traits is to improve the conformation of the cows, equipping them with a functional and reproductive body structure, enabling them to meet the challenges of increasing production.

Knowing the magnitude of the correlations between the type and production traits is important in driving the genetic selection of animals depending on trends seen in the Brazilian market, allowing for the anticipation of the future needs of the herds to obtain more efficient in production and, at the same time, lucrative.

The estimates of genetic correlations between the 21 linear type traits with yield traits ranged from -0.46 to 0.39 for MY, from -0.30 to 0.35 for FY and from -0.47 to 0.34 for PY (Table 4), with most of these correlations being less than 0.20 and the higher estimates were observed with the traits that make up the mammary system section. Forabosco et al. (2009) studied several breeds in 19 countries and highlighted the low MY, along with problems related to udder health of cows, as some of the main factors that affect the longevity of cows in the herd. According to Short and Lawlor (1992) and Sewalem et al. (2004), among all the type traits, traits of section mammary system should receive greater weight in the selection index as they present a positive effect on productive life of cows, second only in importance to the final score.

The high and negative genetic correlations found between the udder depth with MY and FY $(-0.46$ and -0.47 , respectively), suggest that the maintenance of the present emphasis of selection of animals for MY and FY result, as a correlated response, in deep udders, in other words, udder below the line of the hock, which could lead to health

Table 2. Average genetic, phenotypic and residual variance for milk, fat and protein yield in Holstein cows in Brazil

\begin{tabular}{lcccc}
\hline & \multicolumn{4}{c}{ Average variance } \\
\cline { 2 - 5 } & Genetic & Residual & Phenotypic & Heritability \\
\hline Milk yield & $403,384.63$ & $1,537,111.05$ & $1,940,495.67$ & 0.21 \\
Fat yield & 588.30 & $1,846.80$ & $2,435.10$ & 0.24 \\
Protein yield & 292.07 & $1,424.18$ & $1,716.26$ & 0.17 \\
\hline
\end{tabular}


Table 3. Estimates of genetic and residual covariances for linear type traits in Holstein cows in Brazil

\begin{tabular}{|c|c|c|c|c|c|c|}
\hline \multirow{2}{*}{ Linear type traits } & \multicolumn{2}{|c|}{ Milk } & \multicolumn{2}{|c|}{ Fat } & \multicolumn{2}{|c|}{ Protein } \\
\hline & Genetic & Residual & Genetic & Residual & Genetic & Residual \\
\hline \multicolumn{7}{|l|}{ Conformation/capacity } \\
\hline Stature & -9.87 & 114.06 & 0.13 & 2.69 & -0.65 & 4.09 \\
\hline Top line & -27.77 & 31.30 & -0.59 & 1.00 & -0.88 & 1.15 \\
\hline Weight & -25.79 & 109.41 & 0.31 & 3.33 & -1.02 & 4.00 \\
\hline Chest width & -31.29 & 36.63 & -0.42 & 2.24 & -1.09 & 2.09 \\
\hline Body depth & -2.54 & 88.16 & 2.35 & 3.04 & -0.33 & 2.85 \\
\hline Loin strength & 70.02 & 106.31 & 3.42 & 1.58 & 1.48 & 2.73 \\
\hline \multicolumn{7}{|l|}{ Rump } \\
\hline Rump angle & 34.78 & -25.55 & 0.58 & -1.56 & 0.87 & -0.81 \\
\hline Rump width & 24.51 & 112.22 & 0.76 & 3.07 & 0.42 & 3.32 \\
\hline \multicolumn{7}{|l|}{ Legs/feet } \\
\hline Foot angle & 21.20 & 29.09 & 1.22 & 0.70 & 1.26 & 0.70 \\
\hline Bone quality & 58.13 & 117.98 & 2.24 & 2.46 & 1.88 & 3.06 \\
\hline Side view rear legs & -23.28 & -51.51 & 0.54 & -2.08 & -0.47 & -1.67 \\
\hline \multicolumn{7}{|l|}{ Front udder } \\
\hline Fore udder attachment & -33.43 & 96.34 & 0.06 & 4.34 & -0.92 & 3.22 \\
\hline Front teat placement & -9.42 & -8.65 & -0.11 & 0.50 & -0.43 & 0.02 \\
\hline Teat length & 68.4 & -39.8 & 1.27 & -1.39 & 1.07 & -0.47 \\
\hline \multicolumn{7}{|l|}{ Rear udder } \\
\hline Rear udder height & 65.2 & 170.4 & 2.02 & 3.92 & 1.59 & 4.48 \\
\hline Rear udder width & 60.5 & 262.5 & 2.45 & 6.15 & 1.38 & 7.43 \\
\hline Rear teat placement & 77.2 & -62.4 & 1.71 & -1.47 & 1.78 & -1.55 \\
\hline \multicolumn{7}{|l|}{ Mammary system } \\
\hline Udder depth & -151.2 & -106.5 & -3.79 & -1.85 & -4.28 & -2.94 \\
\hline Udder texture & 73.4 & 140.5 & 2.55 & 3.17 & 1.70 & 3.96 \\
\hline Udder cleft & 57.2 & 102.9 & 1.77 & 2.92 & 1.43 & 2.81 \\
\hline \multicolumn{7}{|l|}{ Dairy form } \\
\hline Angularity & 102.92 & 222.62 & 2.96 & 6.08 & 2.47 & 6.10 \\
\hline Final score & -18.32 & 720.12 & 2.39 & 21.16 & -1.13 & 20.93 \\
\hline
\end{tabular}

problems in the cow, such as accidental loss of a teat by stepping on it or through mastitis leading to increased premature and involuntary disposal. According to Rupp and Boichard (1999), Holstein cows with deep udders are commonly culled from French herds as they suffer from problems related to udder health.

As with udder depth, other traits such as the fore udder attachment, front teat placement and fore teat length, showed antagonistic genetic correlations (undesirable) with MY, PY, and FY, but close to nullity, ranging from -0.09 to 0.00. In general, genetic correlations between the type traits were more similar with MY and PY both in direction and in magnitude, than with FY.

In this sense, the loin strength stands out as a unique trait in the conformation section, which showed favorable and positive genetic correlations with the MY (0.22), FY (0.17), and PY (0.28). Thus, the selection of cows with greater loin strength and, therefore, better support for the udder, tend to present, as an indirect response, progeny with higher yields of milk, fat and protein.
The divergence in the direction and magnitude of the genetic correlation observed between body depth and FY (0.22) compared to MY $(-0.01)$ and PY $(-0.04)$, indicates that selection of cows with greater body depth, should result in progeny with higher yields of fat, but the same could not be verified for MY and PY.

The estimated genetic correlation between the fore udder attachment and MY $(-0.09)$ is much lower than that observed by Esteves et al. (2004) in one of the few studies with dairy cows in Brazil $(-0.31)$, which reported that the more strongly the udder is inserted (connected) to the belly of the cow, the lower the MY. On the other hand, cows with strong inserts are easier to keep free of udder infections and increasing their productive life, show decreased problems related to health of the cow and the rate of involuntary culling.

Moderate, positive and favorable genetic correlations observed between MY (0.22 to 0.39$)$, FY (0.28 to 0.35$)$, and PY (0.17 to 0.34$)$ with loin strength, udder texture and angularity are indicative that considerable common gene 
Table 4. Genetic, phenotypic and residual correlations and their respective standard deviations between type traits with milk, fat and protein yield in Holstein cows

\begin{tabular}{|c|c|c|c|c|c|c|c|c|c|}
\hline \multirow{2}{*}{ Type traits } & \multicolumn{3}{|c|}{ Milk yield } & \multicolumn{3}{|c|}{ Fat yield } & \multicolumn{3}{|c|}{ Protein yield } \\
\hline & Genetic & Residual & $\overline{\text { Phenotypic }}$ & Genetic & Residual & Phenotypic & Genetic & Residual & Phenotypic \\
\hline \multicolumn{10}{|l|}{ Conformation/capacity } \\
\hline Stature & $-0.02 \pm 0.06$ & $0.10 \pm 0.02$ & 0.07 & $0.01 \pm 0.06$ & $0.07 \pm 0.02$ & 0.05 & $-0.05 \pm 0.06$ & $0.12 \pm 0.02$ & 0.07 \\
\hline Top line & $-0.12 \pm 0.08$ & $0.03 \pm 0.01$ & 0.00 & $-0.07 \pm 0.07$ & $0.03 \pm 0.02$ & 0.01 & $-0.15 \pm 0.08$ & $0.04 \pm 0.01$ & 0.01 \\
\hline Weight & $-0.08 \pm 0.07$ & $0.10 \pm 0.02$ & 0.06 & $0.02 \pm 0.06$ & $0.09 \pm 0.02$ & 0.07 & $-0.12 \pm 0.07$ & $0.12 \pm 0.07$ & 0.07 \\
\hline Chest width & $-0.11 \pm 0.08$ & $0.03 \pm 0.02$ & 0.00 & $-0.04 \pm 0.07$ & $0.05 \pm 0.02$ & 0.03 & $-0.14 \pm 0.08$ & $0.06 \pm 0.01$ & 0.02 \\
\hline Loin strength & $0.22 \pm 0.08$ & $0.09 \pm 0.02$ & 0.12 & $0.28 \pm 0.08$ & $0.04 \pm 0.02$ & 0.09 & $0.17 \pm 0.08$ & $0.07 \pm 0.02$ & 0.09 \\
\hline \multicolumn{10}{|l|}{ Rump } \\
\hline Rump angle & $0.12 \pm 0.07$ & $-0.03 \pm 0.02$ & 0.01 & $0.05 \pm 0.06$ & $-0.05 \pm 0.02$ & -0.02 & $0.11 \pm 0.07$ & $-0.03 \pm 0.02$ & 0.00 \\
\hline Rump width & $0.06 \pm 0.06$ & $0.11 \pm 0.02$ & 0.10 & $0.05 \pm 0.06$ & $0.08 \pm 0.02$ & 0.08 & $0.04 \pm 0.08$ & $0.10 \pm 0.02$ & 0.09 \\
\hline \multicolumn{10}{|l|}{ Legs and Feet } \\
\hline Foot angle & $0.10 \pm 0.09$ & $0.02 \pm 0.01$ & 0.03 & $0.16 \pm 0.09$ & $0.01 \pm 0.02$ & 0.04 & $0.23 \pm 0.10$ & $0.02 \pm 0.01$ & 0.05 \\
\hline Bone quality & $0.18 \pm 0.08$ & $0.09 \pm 0.02$ & 0.11 & $0.18 \pm 0.07$ & $0.05 \pm 0.02$ & 0.08 & $0.22 \pm 0.08$ & $0.08 \pm 0.02$ & 0.10 \\
\hline \multicolumn{10}{|l|}{ Front udder } \\
\hline Fore udder attachment & $-0.09 \pm 0.07$ & $0.06 \pm 0.02$ & 0.03 & $0.00 \pm 0.07$ & $0.08 \pm 0.02$ & 0.06 & $-0.09 \pm 0.08$ & $0.07 \pm 0.01$ & 0.04 \\
\hline Front teat placement & $-0.03 \pm 0.07$ & $-0.01 \pm 0.02$ & -0.01 & $-0.01 \pm 0.06$ & $0.01 \pm 0.02$ & 0.01 & $-0.04 \pm 0.07$ & $0.00 \pm 0.02$ & -0.01 \\
\hline Teat length & $0.17 \pm 0.06$ & $-0.04 \pm 0.02$ & 0.02 & $0.08 \pm 0.06$ & $-0.04 \pm 0.02$ & 0.00 & $0.10 \pm 0.07$ & $-0.02 \pm 0.02$ & 0.01 \\
\hline \multicolumn{10}{|l|}{ Rear udder } \\
\hline Rear udder height & $0.19 \pm 0.08$ & $0.14 \pm 0.02$ & 0.15 & $0.16 \pm 0.07$ & $0.09 \pm 0.02$ & 0.11 & $0.18 \pm 0.08$ & $0.12 \pm 0.02$ & 0.13 \\
\hline Rear udder width & $0.19 \pm 0.09$ & $0.19 \pm 0.02$ & 0.19 & $0.20 \pm 0.08$ & $0.13 \pm 0.02$ & 0.15 & $0.16 \pm 0.09$ & $0.18 \pm 0.02$ & 0.18 \\
\hline Rear teat placement & $0.27 \pm 0.08$ & $-0.05 \pm 0.02$ & 0.01 & $0.15 \pm 0.08$ & $-0.04 \pm 0.02$ & 0.01 & $0.23 \pm 0.09$ & $-0.04 \pm 0.02$ & 0.01 \\
\hline \multicolumn{10}{|l|}{ Mammary system } \\
\hline Udder depth & $-0.46 \pm 0.09$ & $-0.10 \pm 0.02$ & -0.18 & $-0.30 \pm 0.08$ & $-0.05 \pm 0.02$ & -0.11 & $-0.47 \pm 0.10$ & $-0.09 \pm 0.02$ & -0.17 \\
\hline Udder texture & $0.39 \pm 0.00$ & $0.12 \pm 0.00$ & 0.16 & $0.35 \pm 0.00$ & $0.08 \pm 0.00$ & 0.12 & $0.34 \pm 0.00$ & $0.11 \pm 0.00$ & 0.14 \\
\hline Udder cleft & $0.15 \pm 0.08$ & $0.07 \pm 0.02$ & 0.09 & $0.12 \pm 0.08$ & $0.06 \pm 0.02$ & 0.07 & $0.14 \pm 0.08$ & $0.06 \pm 0.02$ & 0.08 \\
\hline \multicolumn{10}{|l|}{ Dairy form } \\
\hline Angularity & $0.38 \pm 0.09$ & $0.21 \pm 0.02$ & 0.25 & $0.29 \pm 0.08$ & $0.17 \pm 0.02$ & 0.19 & $0.34 \pm 0.10$ & $0.19 \pm 0.02$ & 0.22 \\
\hline
\end{tabular}

action exists between the traits present in different sections, and it can be expected, to a greater or lesser degree, that the progeny of cows will show higher MY, udders with greater elasticity, larger spring of ribs and low fat deposits, leading to progeny with greater dairy ability.

The election of final score by artificial insemination centers as a marketing tool for the sale of semen from bulls in Brazil, as well as the adoption as a selection criterion by farmers over the past few years (McManus and Saueressing, 1998) to improve all type traits simultaneously in the herd, will not lead to significant changes in the volume (MY) and quality (FY and PY) of milk produced by cows, as a certain genetic independence (low correlated response) between these traits (Table 4) is noted, with, greater dependence between environmental factors, due to the moderate residual correlation observed between MY, FY, and PY (>0.23).

Thus, the use of a selection index covering both productive and type or functional traits may be an interesting tool to carry out genetic selection of animals in the Brazilian herd. Sewalem et al. (2004) noted that the final score has the most significant effect on the longevity of Holstein cows, followed by the mammary system traits and feet and legs.

With the exception of final score, described earlier, the angularity of the cows was the trait that showed higher residual correlation with MY (0.21), FY (0.17), and PY (0.19), followed by height and rear udder width (Table 4). Knowing that these traits have suffered, in part, less influence from environmental factors, the study highlights the need for better standardization in how to measure the production or classification of cows to minimize the influence of small environmental effects common to various production and type traits.

Residual correlation values, lower than those obtained by angularity, were observed between all the type traits with MY, FY, and PY, where most were close to nullity (Table 4), suggesting that these two categories of traits are not influenced by the same environmental factors.

For the vast majority of the 21 linear type traits, estimates of phenotypic correlations between traits with MY, FY, and PY were positive and smaller than those observed for the genetic correlation (Table 4). In general, phenotypic correlations were close to zero, except for angularity $(0.25)$, height and rear udder width and udder texture $(>0.15)$. This 
phenotypic correlation between MY and angularity is in accordance with the values of 0.14 and 0.29 reported by Esteves et al. (2004) and McManus and Saueressig (1998), respectively, in Brazilian herds.

The average estimate of phenotypic correlation between final score and production traits (0.20) indicates that, phenotypically, cows with higher balance between type traits, due higher final score, tend to present higher MY, FY, and PY. According to Esteves et al. (2004), the final score deserves special attention, since this trait expresses the balance of the cow for all type traits. This balance indicates the degree of harmony between these traits, as cows with greater productive live, have better functional capacity and lower incidence of disease (Campos et al., 2012).

Although the genetic relationship between type and production traits suggest little genetic progress in increasing the MY of cows through indirect selection for various type traits, several studies (Degroot et al., 2002; Freitas et al., 2002; Pérez-Cabal et al., 2006; Lagrotta et al., 2010) reported that some type traits may influence herd management and therefore should be included in the selection process, due to both their economic and animal welfare, and that, to prevent deterioration and eventually lead to improved functional traits (such as longevity), it is important to consider them for economic and social reasons.

It is important to note the increasing demand for specialization in Brazilian dairy farms, with the need to adapt to the quantitative and qualitative requirements determined by processing industries and by Brazilian government (Normative Instructions 51 and 62). The demand from dairy farmers for improvements in genetic resources of their herds can be quickly met by identifying the best animals through their genetic merit, resulting from genetic evaluations for the traits of greatest interest and that represent breeding goals for breed.

However, due to the complexity of the genetic relationships among the type traits with the three production traits (MY, FY, and PY) and the search for improvements in the sustainability of dairy cattle production, the use of index selection seems to be the most suitable tool for selection of bulls and Holstein cows in Brazil.

\section{CONCLUSION}

In general, significant improvements in breeding values for MY, FY, and PY cannot be expected when practicing genetic selection for most type traits. However, considering the emphasis on selection for increased MY, applied historically to Holstein cattle in various production systems in Brazil, considerable importance should be given to genetic antagonism observed between some type traits and production traits, to avoid deterioration of these or other correlated traits (such as longevity and reproduction traits).
The estimated additive genetic variability for most type and production traits suggests the possibility of genetic improvement through direct selection. However, considering the complexity of genetic relationships between many observed traits, index selection appears to be the most suitable tool for the selection of Holstein bulls and cows in Brazil, aimed, mainly, at the increase in genetic gains in all traits of interest for the sustainability of dairy farming.

\section{ACKNOWLEDGMENTS}

Thanks are due to the Brazilian Holstein Breeders Association for the data, the Coordination of Improvement of Higher Level Personnel and National Council of Scientific and Technological Development for scholarships.

\section{REFERENCES}

Boligon, A. A., P. R. N. Rorato, G. B. B. Ferreira, T. Weber, C. J. Kippert and J. Andreazza. 2005. Heritability and genetic trend for milk and fat yields in holstein herds raised in the state of Rio Grande do Sul. Rev. Bras. Zootec. 34:1512-1518.

Boldman, K. G., L. A. Kriese, L. D. Van Vleck, C. P., Van Tassell and S. D. Kachman. 1995. A manual for use of MTDFREML: a set of programs to obtain estimates of variances and covariances. ftp://aipl.arsusda.gov/pub/outgoing/mtdfreml/ mtdfrman.pdf Accessed May15, 2013.

Brazil. 2011. Technical regulation of production, identity and quality of refrigerated raw milk. In: BRAZIL. Ministry of Agriculture, Livestock and Supply. Normative Instruction No. 62 of Dec. 29, 2011. Federal Official Gazette of Brazil, No. 172, p. 6, Dec. 30, 2011, Section 1. (In Portuguese).

Campos, R. V. 2012. Genetic Parameters for Linear Type and Yield Traits in Holstein Cows in Brazil. Ph.D. Thesis, Federal University of Rio Grande do Sul, Porto Alegre, Brazil.

Campos, R. V., J. A. Cobuci, C. N. Costa, and J. B. Neto. 2012. Genetic parameters for type traits in Holstein cows in Brazil. Rev. Bras. Zootec. 41:2150-2161.

Cardoso, V. L., J. R. Nogueira, A. E. V. Filho, L. El Faro, and N. C. Lima. 2004. Breeding goals and economic values for pasture based milk production systems in the southeast region of Brazil. Rev. Bras. Zootec. 33:320-327.

Costa, C. N., J. A. Cobuci, A. A. Valloto, and M. F. Martins. 2011. National summary of Holstein bulls - 2011, Juiz de Fora: Embrapa Dairy Cattle. 40 p. (Series Documents No. 149).

Costa, J. H. C., M. J. Hötzel, C. Longo, and L. F. Balcão. 2013. A survey of management practices that influence production and welfare of dairy cattle on family farms in southern Brazil. J. Dairy Sci. 96:307-317.

Daliri, Z., S. H. Hafezian, A. Shad Parvar, and G. Rahimi. 2008. Genetic relationships among longevity, milk production and linear type traits in Iranian Holstein Cattle. J. Anim. Vet. Adv. 7:512-515.

Degroot, B. J., J. F. Keown, L. D. Van Vleck, and E. L. Marotz. 2002. Genetic parameters and responses of linear type, yield traits, and somatic cell scores to divergent selection for predicted transmitting ability for type in Holsteins. J. Dairy Sci. 
85:1578-1585.

Esteves, A. M. C., J. A. G. Bergmann, M. C. Durães, C. N. Costa, and H. M. Silva. 2004. Study of environmental effects on linear type traits in Brazilian Holstein. Arq. Bras. Med. Vet. Zootec. 56:522-528.

Forabosco, F., J. H. Jakobsen, and W. F. Fikse. 2009. International genetic evaluation for direct longevity in dairy bulls. J. Dairy Sci. 92: 2338-2347.

Freitas, A. F., N. M. Teixeira, M. C. Durães, M. S. Freitas, and R. B. Barra. 2002. Genetic parameters for linear udder traits, final score and milk and fat yields in Holstein. Arq. Bras. Med. Vet. Zootec. 54: 485-491.

Kern, E. L., J. A. Cobuci, C. N. Costa, and C. M. McManus. 2014. Factor analysis of linear type traits and their relation with longevity in Brazilian Holstein cattle. Asian Australas. J. Anim. Sci. 27:784-790.

Lagrotta, M. R., R. F. Euclydes, R. S. Verneque, M. L. Santana Júnior, R. J. Pereira, and R. A. Torres. 2010. Relationship between morphological traits and milk yield in Gir breed cows. Pesq. Agropec. Bras. 45:423-429.

Mark, T. and P. G. Sullivan. 2006. Multiple-trait multiple-country genetic evaluations for udder health traits. J. Dairy Sci. 89: 4874-4885.

Martins, P. C. and A. V. Carneiro. 2012. Brazilian will consume more milk in 2012. In: Anualpec: Yearbook of Brazilian Livestock. FNP - Informa Economics South America. São Paulo: FNP, 225-228.

McManus, C. and M. G. Saueressig. 1998. Study of linear type traits in Holstein-Friesian cattle in total confinement in the Distrito Federal. Rev. Bras. Zootec. 27:906-915.

Miglior, F., B. L. Muir, and J. Van Doormaal. 2005. Selection Indices in Holstein cattle of various countries. J. Dairy Sci. 88: 1255-1263.

Misztal, I., T. J. Lawlor, T. H. Short, and P. M. Van Raden. 1992. Multiple-trait estimation of variance components of yield and type traits using an animal model. J. Dairy Sci. 75:544-551.

Pérez-Cabal, M. A. and R. Alenda. 2002. Genetic relationships between lifetime profit and type traits in Spanish Holstein cows. J. Dairy Sci. 85:3480-3491.
Perez-Cabal, M. A., C. Garcia C, O. Gonzalez-Recio, and R. Alenda. 2006. Genetic and phenotypic relationships among locomotion type traits, profit, production, longevity, and fertility in Spanish dairy cows. J. Dairy Sci. 89:1776-1783.

Posadas, M. V., H. H. M. Valdenegro, and F. J. R. López. 2008. Genetic parameters for conformation traits, stayability and milk yield for Holstein dairy cattle in Mexico. Téc. Pecu. Méx. 46:235-248.

Renno, F. P., C. V. Araujo, J. C. Pereira, M. S. Freitas, R. A. Torres, L. N. Renno, J. A. G. Azevedo, and F. R. Kaiser. 2003. Genetic and phenotypic correlations among type traits and milk yield of Brown Swiss cattle in Brazil. R. Bras. Zootec. 32:14191430.

Rupp, R. and D. Boichard. 1999. Genetic Parameters for clinical mastitis, somatic cell score, production, udder type traits, and milking ease in first lactation Holsteins. J. Dairy Sci. 82:21982204.

Sewalem, A., G. J. Kistemaker, F. Miglior, and B. J. Van Doormaal. 2004. Analysis of the relationship between type traits and functional survival in Canadian Holsteins using a Weibull Proportional Hazards Model. J. Dairy Sci. 87:3938-3946.

Short, T. H. and T. J. Lawlor. 1992. Genetic parameters of conformation traits, milk yield, and herd life in Holstein. J. Dairy Sci.75: 1978-1998.

Silva, D. A. R.,C. J. Olivo, B. C. Campos, T. M. Tejkowski, G. R. Meinerz, A. G. F. Saccol and S. T. da Costa. 2011. Milk production of Holstein cows in small, medium and large size. Ciênc. Rural. 41:501-506.

Simianer, H., H. Solbu, and L. R. Schaeffer. 1991. Estimated genetic correlations between disease and yield traits in dairy cattle. J. Dairy Sci. 74:4358-4365.

Valotto, A. A. and G. R. Neto. 2010. Holstein breed modernizes and updates the evaluation system of the conformation of cows (type classification). http://www.gadoholandes.com.br Accessed March 16, 2013.

Vanraden, P. M. 2004. Invited review: Selection on net merit to improve lifetime profit. J. Dairy Sci. 87:3125-3131.

Wenceslau, A. A., P. S. Lopes, R. L. Teodoro, R. S. Verneque, R. F. Euclydes, W. J. Ferreira, and M. A. Silva. 2000. Estimate of genetic parameters of conformation traits, milk production and age at first calving in dairy Gyr breed cows. Rev. Bras. Zootec. 29:153-158. 